\title{
On the development of the clitic postposition category in Estonian*
}

\section{Introduction}

The clitic postpositions are a recent innovation in Estonian, arising as a definite category by the mid sixteenth century, early seventeenth century. The four clitic postpositions - the comitative, abessive, terminative, and essive (acronymically the CATE morphemes) - have arrived in this category via diverse paths. These developments are explored here and relevant theoretical issues brought out.

\subsection{What's a clitic?}

A clitic is a morpheme, possibly morphologically complex, having a mixed word/affix status. This is to say that it has some properties of words and some properties of affixes. Both diachronically and synchronically the clitic appears to be intermediate between the word and the affix.

Continuing along the lines of previous work (Nevis 1985), I adopt the position that clitics are not primitive units of the grammar, but are deriva-

\footnotetext{
*I thank Rich Janda for discussion of some of the terminology; he is not, however, responsible for all of the shortcomings of the terminological selections. In addition, I thank Ilse Lehiste for having taught me Estonian in the first place, for acting at times as respondent and consultant, and for commenting on early (1982) drafts of this work. Parts of this paper were presented in Brian Joseph's (1982) OSU seminar on historical syntax-morphology, and I thank him for comments at that time. In 1983 - 84 I was on fellowship at the University of Helsinki (thanks to the American-Scandinavian Foundation and the U. S. Educational Foundation in Finland), where I was able to continue this line of research. Professor Seppo Suhonen of the Department of Baltic Finnic was very helpful in discussing the work of the older grammarians. In addition, I thank Jarmo Elomaa for being my "vastaväittäjä" when I presented some of this material in Suhonen's UH Baltic Finnic seminar. Finally, I note that I presented sections 4 and 6 to the fourth annual meeting of the Finno-Ugric Studies Association of Canada, Winnipeg (Nevis 1986d), and that the data in section 4.1. came from Professor Raija Bartens' (spring 1984) lectures on Uralic morphology and syntax at the University of Helsinki.
} 
tive from other primitive units. In particular I argue that clitics fall into two groups - derivative words and special affixes. The derivative words are words that, in addition to their regular syntactic properties, are attached phonologically to a neigbour. These are the bound words. The special affixes are like regular affixes, except that they attach phrasally, rather than lexically. These are the phrasal affixes.

Bound words acquire their phonological status through a post-syntactic, post-lexical phonological linking rule of lialson. Phrasal affixes are assigned to their hosts by a syntactic rule similar to rules assigning regular inflectional affixes, only at the margins or head of the constituent. Thus cliticization is not to be understood here as a synchronic operation; instead, the synchronic rules are liaison and phrasal affixation. In what follows, the term cliticization will be used as a diachronic process whereby a word acquires a dependent phonological status.

\subsection{The CATE as clitics in Modern Estonian}

In standard Northern Estonian the CATE endings have a different morphosyntactic behaviour from that of regular case suffixes. In every way that the CATE endings differ from the set of suffixes, they pattern with the set of postpositions.

For example, case suffixes do not permit attachment to just one adjunct in conjoined phrases (e.g. the allative in (1)), whereas the CATE morphemes and postpositions do allow such attachment $(2-3)$

(1) *isa- ja ema-le father and mother-ALL

'to father and mother'

cf. isa-le ja ema-le

(2) isa ja ema-ta

father and mother-ABES

'without father and mother'

cf. also: isa-ta ja ema-ta

(3) isa ja ema ees

father and mother in-front-of

'in front of father and mother' 
cf. also: isa ees ja ema ees

A second difference lies in adjective-noun agreement. Within noun phrases the case suffixes regularly appear on every adjective modifying the head noun (4); CATE morphemes only attach to the head noun, and adjectives in CATE noun phrases are in the genitive (5).
(4) noore-le ajakirjaniku-le young-ALL journalist-ALL
'to the young journalist'
cf. *noore ajakirjaniku-le
(5) noore ajakirjaniku-ta young/GEN journalist-ABES
'without a young journalist'
cf. *noore-ta ajakirjaniku-ta

Again the CATE phrases parallel the postpositional phrases. Postpositions typically govern a genitive (or partitive) case on the accompanying noun phrase:
(6) noore ajakirjaniku ees young/GEN journalist/GEN in-front of 'in front of the young journalist'

There are other syntactic tests that are relevant here, and they all demonstrate that the CATE endings pattern syntactically with the set of postpositions rather than with the class of case suffixes (Nevis 1986b). I analyse the CATE endings as syntactic postpositions which happen to be phonologically attached to the preceding noun (Nevis 1982, 1986b). The term 'clitic postposition' is a convenient label for this Estonian phenomenon - the general label for this kind of clitic is bound word.

Thus the synchronic status of the CATE morphemes is mixed. They exhibit syntactic behaviour typical of regular words in the language, yet at the same time they are phonologically proper subparts of words (i.e. phonologically bound).

\subsection{Upgrading and downgrading}

Typically the mixed status of a clitic is indicative of on-going change from full word to affix. As a word loses its semantic strength, becoming semanti- 
cally bleached and more grammatico-functional, it also loses its phonological strength, first becoming unstressed, then phonologically dependent on a neighbour:

WORD $>$ LEANER $>$ BOUND WORD

[where $(7)=$ destressing and $(8)=$ cliticization.] Once the word has become phonologically bound, it is likely to be reinterpreted as a proper subpart of its phonological host, especially if the two are semantically compatible (see Nevis 1986c). Often a bound word is reinterpreted as as a phrasal affix, after which a phrasal affix may be reinterpreted as a regular affix:

BOUND WORD > PHRASAL AFFIX > AFFIX

[where (9) = affixation and $(10)=$ dephrasalization. $\left.{ }^{1}\right]$ These reduction processes may ultimately lead to complete loss, though loss may occur at an earlier stage for reasons other than mere downgrading:

AFFIX $>\emptyset$

[where $(11)=$ loss.]

This scheme is downgrading. It is a tendency only, not an absolute direction of language change, since a stage may be relatively stable without being subject to downgrading, since lower stages do not necessarily arise as a result of downgrading from a higher stage, and since the reverse sequence, i.e. upgrading, is also a (remote) possibility.

Upgrading has been known to occur in English with phrasalization of genitive -(e)s (Janda 1981), in Northern Sámi with deaffixation of abessive -taga (and subsequent decliticization of -taga in the Enontekiö dialect Nevis 1986a), and in Old Estonian with decliticization of its Wackernageltype bound words (Nevis 1986c):

\footnotetext{
${ }^{1}$ The terminology here is not standard. In order to more accurately describe stages in upgrading and downgrading I have had to invent some new labels. The terms upgrading and downgrading come from Rich Janda (p.c.). The downgrading and upgrading scheme presented here is somewhat of an elaboration of the terminology used by Jeffers and Zwicky (1980); in particular, my use of cliticization and decliticization are much more restricted than theirs.
} 


\section{AFFIX $>$ PHRASAL AFFIX > BOUND WORD > LEANER > WORD}

[where (12) = phrasalization, (13) = deaffixation, (14) = decliticization, and $(15)=$ stressing.]

Despite the exceptions, we can still identify downgrading as the overwhelming tendency and default change (in comparison with upgrading). We need to isolate the factors that mitigate against downgrading and determine when upgrading is possible and/or probable.

A serious question which will not be answered here is whether the downgrading stages can be skipped in language change. Is it possible, for example, that a bound word need not go through a phrasal affix stage on its way to becoming a regular affix? Or must every intermediate stage be present in downgrading?

Only the comitative facts follow the path of downgrading. The essive shows instability - early loss and later reintroduction. The abessive and terminative are examples of upgrading - in particular, deaffixation.

\section{Comitative -ga}

The comitative clitic postposition $-9 a$ developed from the full postpositions *kansak, *kansassa, ?*kansahen in the middle of the sixteenth century (for Southern Estonian) and at the beginning of the seventeenth century (for Northern Estonian). Before then, the earliest Estonian texts show full postpositions 〈kas, kaes, kaas, kaass, kahs; kaen, koen, kahn, gan〉, as in (16) below. Later these postpositions exhibit reduced phonology, e.g. 〈kah, kaa, ka, -ga> (Oinas 1961: 27 - 32), cf. (17). Thus we can follow the agglutination of the postposition into its clitic form: *kansak $>*_{k} k a a s a k>k a a s>k a a>k a$ $>-G a$ (Rätsep 1979: 78). This phenomenon has been well described as an example of a suffix developing from a free word (cf. Tauli 1966: 113, Callaghan 1972: 383, Stoebke 1968: 112, Comrie 1980: 81 - 82, and Rätsep 1979: 77 - 80, among many others).

$$
\begin{aligned}
& \text { (16) Issan kaes (Rätsep 1979: 78) } \\
& \text { 'with father' } \\
& \text { =/isa-n kaas/ } \\
& \text { father-GEN with }
\end{aligned}
$$




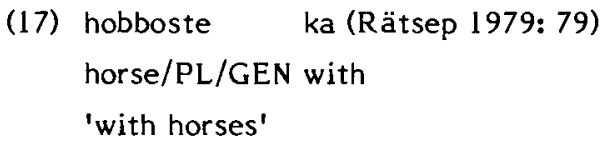

Oinas (1961: 30 - 31) traces the development of the comitative in Estonian. According to his description, the bound forms first appear in Southern Estonian, e.g. in works by Laurentius Boierus (during 1587 - 95) and in Agenta Parva (1622), the latter with hyphenated =ga (Saareste 1938: 200, Rätsep 1979: 79), as in (18). In Northern Estonian the bound variants first appear in Hornung's 1693 works. In addition to Oinas' citations, one should mention Wiedemann's (1875: 323fn) mention of Gutsleff's (1648) Observationes Grammaticae circa linguam Esthonicam, where the comitative ending is considered a "suffixed postposition".

(18) kätte-ga nink yalgu-ga (Rätsep 1979: 79)

hands-COM and feet-COM

'with hands and feet'

Wiedemann himself argues emphatically against an analysis of the comitative $-g a$ as a true case suffix. First he notes:

Von -ga... lässt sich die Verflüchtigung vom selbständigen Worte zur blossen Anhangssylbe noch verfolgen. In den ältesten ehstnischen Schriften erscheint es als kās, dann als $k \bar{a}$, und jetzt ist seine Untrennbarkeit vom dem vorhergehende Worte besiegelt durch den Uebergang des $k$ in $g$, womit kein eigentlich ehstnische Wort anfängt. Da kās ... als Postposition ("mit") gebraucht, wie andere Wörter der Art, das vorhergehende im Genitiv verlangte, so wird es auch in seiner jetzigen Gestalt immer nur an denselben Casus gehängt, und bildet so einen Instrumental oder Comitativ, der aber nicht als wirklicher Casus den übrigen ganz gleich zu stellen ist. (1875: 319)

Later he reiterates:

Die Endung -ga ... ist hier nicht als Casusendung angesehen, weil sie nachweisbar eine Postposition ist, die nur ihre Selbständigkeit verloren hat und jetzt dem regierten Nomen angehängt wird. (p. 322)

Interestingly, Wiedemann also draws parallels between the Estonian clitic postposition -ga and the bound postpositions of Hungarian.

The early Estonian grammarians treated comitative -ga as a postposition (Oinas 1961: 34). Included here are, beside Wiedemann: Hornung (1693: 108), Helle (1732), Hupel (1780), and Ahrens (1843). Wiedemann and Heller fur ther 
extend this "enclitic particle" class to the abessive -ta and the terminative $-n i$, though under different names ("Caritiv" = abessive, and "Instructiv" or "Instrumentalis" = terminative).

This development from a full postposition to a clitic explains the syntactic behaviour of the comitative. As a former postposition, -ga would lack agreement for attributes and would be allowed to undergo such syntactic rules as deletion under identity. Since such syntactic properties do not follow from the history of the other three clitic postpositions, it is clear that the clitic postposition category did not become established in the language until the cliticization of comitative $-g a$.

\section{Essive -na}

Raun and Saareste (1965: 64) explain that the essive -na existed in an earlier form of the language (presumably as a suffix as in the other Baltic Finnic languages), but became obsolete in the northern dialects in the 16 th century. It survives, however, in folksongs and in the North-Eastern dialect (Rannikumurre). In the southern dialects, according to Kask (1972: 153), it fell together with inessive $-n,-h$, and $-s$.

\subsection{Borrowing}

The essive clitic postposition in modern Estonian is a borrowing from the North-Eastern dialect and from Finnish. It had been introduced in the middle of the 19 th century by $\mathrm{E}$. Ahrens at a time when the literary language was undergoing considerable development and language planning (Raun and Saareste 1965: 72), but it did not catch on at that time. It was revived at the turn of this century by Johannes Aavik and finally adopted into the literary language (Raun and Saareste, p. 76). The essive clitic is therefore the most recent of the four clitic postpositions in Estonian.

The essive inherited from Proto-Balto-Finnic did not trigger consonant gradation since it did not close the preceding syllable. Therefore it at tached to the strong degree of the stem. In the Old Estonian texts one finds strong stems. Ahrens (1853), for example, has nahkana 'as skin, leather', leskena 'as a widow', and uudena 'as new' (Kettunen 1956: 19), where modern Estonian 
has weak stems nahana, lesena, and uuena. How much these Old Estonian essives reflect Finnish influence is open for debate (Kettunen 1956: 19 - 20, Rätsep 1979: 64). The weak stem in the modern essive is a result of the inclusion in the clitic postposition category (ultimately due to the former genitive in the comitative postposition phrase). The strong stemmed essive has survived in relic forms (e.g. in archaic folk poetry) and to a certain extent in the dialects (Rätsep 1979: 64).

This loss and reintroduction of the essive case has created an unusual situation in the morphosyntax and semantics of Estonian. The essive, which had been a stative, non-directional case, had been in complementary distribution with the translative, a non-stative, directional case. This older situation still exists in Finnish, where the essive is used with stative, non-directional verbs (e.g. olla opettaja-na 'to be (as) a teacher') and the translative $-k s i$ is used with directional verbs (e.g. tulla opettaja-ksi 'to (be)come a teacher').

In Old Estonian the essive was replaced by other case endings, notably the translative. When the essive was reintroduced in the late 19 th century, it came to contrast semantically with the translative: (from Lehiste 1969: 333)

(19) N. N. on meie saadik Londonis

N. N. is our ambassador London-INES

'N. N. is our ambassador in London'

(20) N. N. on meie saadiku-ks Londonis

N. N. is our ambassador-TRANS London-INES

'N. N. is acting as our ambassador in London'

(21) N. N. on meie saadiku-na Londonis

N. N. is our ambassador-ESS London-INES

'N. N. is temporarily our ambassador in London'

\subsection{Institutionalized borrowing}

This type of borrowing seems to be a rarity in the diachrony of the languages of the world. Although few linguists would argue against the possibility of grammatical or morphological borrowing, even Roman Jakobson (1971) would constrain this kind of borrowing to structural elements that 
correspond to structural tendencies already present in the language. Obviously the structural tendency to eliminate the essive case caused its decline in the 16th century in the first place. Furthermore, the fact that the language still rejected the essive when Ahrens first reintroduced it in 1843 and 1853 shows that Estonian lacked such an affinity in the 19th century (Raun and Saareste 1965: 72). It was not until Aavik revived it at the turn of this century that the language reluctantly accepted it.

Thomason (1981) discusses several instances of grammatical and morphological borrowing, but still limits it to certain conditions:

If there is strong cultural pressure from the source-language speakers on the borrowing-language speaker group, then structural features may be borrowed as well [as lexical items] - phonological, phonetic, syntactic, and even (though much more rarely) features of the inflectional morphology. But the strong cultural pressure must apparently include institutionalized bilingualism in order for nonlexical borrowing to occur. (p. 8)

While as a general principle I would like to agree with Thomason, the example of the Estonian essive contradicts even the last statement. To my knowledge there was not institutionalized bilingualism among Estonian speakers (Finnish-Estonian bilingualism, that is) in the 19th century. The Estonian borrowing of the essive -na may thus constitute an interesting counterexample demonstrating that even Thomason's already weak prerequisite for contact-induced change must be further weakened.

Her principle can be salvaged, however, if one considers that essive -na was introduced into Standard Estonian as part of language planning. The borrowing is thus in some sense institutionalized - it spread by literary and educational means. In addition, the close linguistic relationship between Finnish and Estonian must not be overlooked in evaluating the contribution of this example to Thomason's principle.

\section{Abessive -ta}

As bound forms, abessive -ta and terminative $-n i$ are much older than comitative -ga. The comitative cliticized in Estonian only in the past few hundred years. The abessive and terminative, by contrast, can be traced back several thousand years as bound morphemes. Although phonologically 
bound, the age of the abessive and the terminative do not correspond to the age of the clitic postposition category in the language. I adopt the position here that the clitic postposition is a recent innovation in Estonian and $\mathrm{I}$ support that position with comparative and language-internal evidence.

\subsection{Comparative evidence}

Abessive -ta is an ancient morpheme in Finno-Ugric. There are cognate abessives in most of the Finno-Permic languages, all continuing directly the bound morpheme reconstructed as *-pta-k (with lative *-k suffix), cf. Korhonen (1974: 173 - 176, 1979: 11):

(22) ABESSIVE CASE ENDING *-pta-k:

Sámi -pta, -t'ta, -taga

Finnish -tta', -ttä'

Mordvin $\emptyset$

Mari -te, -de

Udmurt -tek

Komi -teg

There is no evidence whatsoever that *-pta was ever a free morpheme. Such a view would require independent agglutination in all the Finno-Permic languages. There is instead evidence that it has always been suffixal. Support for this view comes from two areas. First, many languages show *-pta inside another suffix in the adjective formants *-pta-ma (on the FinnoPermic side) and *-pta-l (on the Ugric side), see also Décsy (1965: 159, 182):

(23) CARITIVE ADJECTIVAL SUFFIXES:

$$
\begin{array}{ll}
\text { FINNO-PERMIC *-pta-ma } \\
\text { N. Sámi } & \text {-tæbme } \\
\text { Finnish } & \text {-ton, -ttoma- } \\
\text { Mordvin } & \text {-vtomo, -vteme; -ftama, -f təma } \\
\text { Mari } & \text {-təm, -dəm } \\
\text { Udmurt } & \text {-tem } \\
\text { Komi } & \text {-tem } \\
\text { UGRIC *-pta-1 } \\
\text { Khanti } & \text { (-tam, -tem borrowed from Komi) } \\
\text { Mansi } & \text {-tal, -täl }
\end{array}
$$


The second source of support for an affixal analysis of *-pta comes from shared relic forms inherited from the Finno-Ugric parent language. Nearly all the Finno-Ugric languages exhibit verbal abessives in which the abessive case ending attaches directly to the verb stem. Such attachment is idiosyncratic and unpredictable from other facts in the languages at hand, since case affixes usually require the verb to be nominalized before a case can be added:

(24) VERBAL ABESSIVES:

$\begin{array}{ll}\text { N. Sámi } & \text { (-tæbme from adjectives) } \\ \text { Finnish } & \text {-tta', -ttä' } \\ \text { Mordva } & \emptyset \\ \text { Mari } & \text {-de } \\ \text { Udmurt } & \text {-tek } \\ \text { Komi } & \text {-teg } \\ \text { Khanti } & \text {-ləү, -лiək, -ләү }\end{array}$

The Comparative Method requires that abessive * for Proto-Finno-Ugric. In conjunct with lative *-k it has turned into the modern case endings of (21); in conjunct with nominalizers *-ma and *-l, it has become the adjectival endings of (22). It was then clearly a suffix in the parent language.

In the course of several thousand years of development, abessive *pta has acquired a few idiosyncracies, such as the attachment to a bare verb stem without an intervening nominalizing suffix. In conjunct with a derivational suffix it has univerbated into a monomorphemic adjectival suffix: e.g. Estonian -tu < $<$-tton $<*$-ttoin $<*$-ttoim <*-ttaim $<*$-ttami $<*$-ttama $<$ *-pta-ma, see Hakulinen (1979: 183).

These two idiosyncracies lead me to suppose that abessive *-pta was a derivational suffix rather than an inflectional suffix. It is generally accepted that derivational affixes universally lie outside inflectional affixes (as well as other derivational affixes), as in (25), but inflectional affixes never lie inside derivational affixes with respect to the base, as in 826).

(25) INFL-DER-BASE-DER-INFL

(26) *DER-INFL-BASE or *BASE-INFL-DER

Since *-pta came between the base and the derivational suffixes *-ma and $*_{-l}$ (both nominalizers), we can assume that *-pta, too, was derivational. 
The second reason to assume a derivational status for *-pta comes from the nature of its host selection. Inflectional affixes are generally restricted to one stem-type in terms of word class. That is, inflectional affixes will attach to a member of a single word class. For instance, case endings in Estonian attach productively only to nominal stems, never to verbs, unless the verb has been nominalized. Derivational affixes, on the other hand, are known to sometimes attach promiscuously to a stem of a particular semantic category, with no regard to word class. For example, the adverb formant $-l i$ can attach to all three major word classes in Estonian (i.e. noun, verb, adjective, and even numeral), albeit semi-productively.

(27) NOUN küli-li, külje-li 'on one's side'

$$
\text { cf. külg 'side' }
$$

VERB istu-li, 'in a sitting manner'

$$
\text { cf. istu-ma 'to sit' }
$$

ADJECTIVE laia-li 'spread, dispersed, scattered'

$$
\text { cf. lai 'broad, wide' }
$$

NUMERAL kahe-li 'in twos'

$$
\text { cf. kaks 'two' }
$$

Consequently, when an affix can attach to both noun and verb stem classes, one suspects the affix of being derivational rather than inflectional.

\subsection{Morphosyntacticization and deaffixation}

The problem now is to relate the former derivational suffix *-pta to the modern Estonian clitic postposition -ta. First one has to allow for the change in morphological status - the derivational suffix has become inflectional. Second, the affix has to acquire a certain loose morphological and phonological status.

The change in morphological status came about through the univerbation of the derivational abessive *-pta and inflectional lative *-k. Once the morpheme boundary disappears and the *-pta-k unit becomes productive, it is reinterpreted as an inflectional affix, thereby entering the nominal case system. This change took place in Finno-Permic, as most of the languages exhibit an abessive as part of their case systems.

The change from affix to bound word (i.e. deaffixation - with probable 
phrasal affix; see below section 6.1.) took place at a relatively late stage. It is restricted to Estonian (but occurs independently in some of the Sámi languages; see Nevis 1986a). All the closely related Balto-Finnic languages have affixal abessives - Finnish, Karelian, Vepsian, and Votian. (I have insufficient data to evaluate Livonian, which may share the clitic postposition abessive with Estonian or may parallel the other Balto-Finnic languages in having an affixal abessive.)

\section{Terminative $-n i$}

The origin of the terminative in Estonian is unclear. It occurs in the other Balto-Finnic languages, so one reconstructs it for the parent language. The terminative is nevertheless used productively only in Estonian. It is found only in a few forms in the sister languages.

\subsection{Terminative 'particles'}

The terminative word-forms found in Baltic Finnic include adverbs, conjunctions, and postpositions - generally known as 'particles' in Finnish linguistics (Penttilä 1957: 327 - 328, Hakulinen 1979: 73). Diachronically there appears to be change from one word class to another fairly readily. And synchronically the boundaries among adverb, conjunction, and postposition are not always clear. For these reasons I shall retain the use of the term 'particle', though its use is otherwise obstructive and unenlightening.

The particles can be divided into subgroups according to form and meaning. The -nne- particles are all terminative in meaning; the $f(n) n i-$ particles are more modal in their semantics, but can have terminative nuances (Mägiste 1959). In both groups there is either a *-k lative or *-s lative ending or no ending at all:

(28) -nne-
A. $-n n e-k$
B. -nne-s
C. ?-nne

(29) -(n)ni-

A. $-n n i-k$ 


$$
\begin{aligned}
& \text { B. }-n n i-s \\
& \text { C. }-n n i \\
& \text { D. }-n i,-n i-k,-n i-s
\end{aligned}
$$

Collinder (1960: 294, 1965: 126) separates the Finnish forms in -ni (kuni, sini, mini, täni) from the forms in -nne- (jonne, kunne, minne, kahtaanne, etc.) and the Estonian terminative. He links the former to the older ProtoFinno-Ugric dative case ${ }^{*}-n$, to the ${ }^{*}-n$ reconstructed for Proto-BalticFinnic illative *-sen and allative *-len as well as Selkup animate dativelative $-n,-n i,-n y k$, and to the Nganasan lative ${ }^{*} \rightarrow \eta$. Setälä (1890: 383) also distinguishes between the two groups; he has a $-n n e(k)$ lative and a $-(n) n i$ terminative.

Collinder's view has the advantage of keeping distinct the single $n$ and the geminate $n n$ forms in Finnish. The terminative in Estonian would then be cognate to the geminate forms in Finnish and to the Selkup inanimate dative-lative $-n d y,-n d$. This further accounts for the temporal orientation of the single $n$ forms and the spatial (or at least more general) orientation of the geminate $n n$ forms. The latter is to be reconstructed in ProtoBalto-Finnic with a different vowel than the former: terminative $*_{-} n n e-k / s / \theta$ and temporal adverb *-ni(s). Now we have an explanation for the presence of the vowel $i$ (in place of ${ }^{*} e$ ) in Estonian seniks 'as long as, until now', senini 'up to now, hitherto', kuniks 'when, how long', and senikaua 'as long as, while' (and Finnish dialectal sinis, kunis, saanikka); it continues the vowel of $*_{-n i}$ rather than that of ${ }^{*}-n n e-$.

Thus I assume for Proto-Balto-Finnic a set of $*-n i$ adverbs with temporal meaning (29) and a set of *-nne - *nnek - *-nnes adverbs with locative meaning (28), and a certain amount of confusion and crossover between the two.

Frequently occurring in the corpus are the pronominal stems ku- and se-.

(30) ku- particles (Rätsep 1979: 72, Kettunen 1956)

Estonian: kuni - kunni 'until (the time when)'; kuniks 'when, how long'

Finnish: kunne 'where, whither'; kunnes 'until' (= dial. kuni, kuńis)

Karelian: kune - kunna 'until' 
$\begin{array}{ll}\text { Vepsian: } & \text { kuńi 'until' } \\ \text { Livonian: } & \text { kuńt'ś 'until' }\end{array}$

(31) se- particles (Rätsep 1979: 72, Kettunen 1956)

Estonian: seni - senni 'up to'; seniks 'as long as, until now; senini 'up to now, hitherto'

Finnish: sinne - sinnes '(to) there, thither'; dial. sini - sinni 'until then'

Karelian: Šinne - sinna '(to) there, thither'

Vepsian: sińi 'until now'

Votian: sinne $(G)$ '(to) there, thither'

Livonian: seńtśs 'until now'

On the basis of these cognates Rätsep reconstructs *sinnik, *sennik, *sinnis, and *sennik for Proto-Balto-Finnic. In addition, Finnish, Estonian, and Votian use the stem tä-, and in Finnish one also finds pronominal stems joand $m i$.

(32) ta- particles

Estonian: täni(ni) 'up to now, to date, hither to'

Finnish: tänne' '(to) here, hither'; dial. täni 'so much'

Votian: tänne $(G)$ '(to) here, hither'

(33) Finnish jo- and mi-particles

$$
\begin{aligned}
& \text { jonne' 'where, whither' } \\
& \text { minne' 'where, whither' } \\
& \text { OF jonni 'so long as' } \\
& \text { dial. mini "bis zu welchem Masse" }
\end{aligned}
$$

Finnish seems to have the second largest set of terminative particles, though this is probably an artifact of the depth of description for Finnish vis-à-vis the other Balto-Finnic languages.

(34) Other Finnish terminatives (Kettunen 1956)

OF täydhenni 'fully'

OF aiwa jurenni "rätt grundligen"

kaikenni 'entirely'

tyynni - tyyni 'entirely'

muuanne' 'in a different direction'

samanne' (päin) 'in the same direction'

toisanne' 'in another direction' 
kahtaanne', dial. kahdaanne' 'in two directions'

yhtäänne', dial. yhdänne' 'in one direction'

The northern Finnish dialects display even more terminative particles (from Kettunen 1956: 9 - 10, Hakulinen 1979: 233):

(35) pohjuni - pohojuni 'biz zum Boden'

perunni' 'biz zum Boden'

juuruni 'ganzlich'

vanhani 'in früherer zeit'

saanni(kka) 'as far as, up to'

5.2. On the origin of the terminative

The productive terminative $-n i$ in Estonian comes from *-nni-k, which lost its final $*-k$ before the thirteenth century and shortened its geminate $-n n-$ to $n$ at the beginning of the fourteenth century (Raun and Saareste 1965: 60, Rätsep 1979: 71).

Collinder (1960) attempts to trace the terminative back to ProtoFinno-Ugric. Mägiste (1959) reconstructs it only for Proto-Balto-Finnic. And Alvre (1971, 1972, 1974) argues it to be an Estonian innovation.

What is clear from the lists of particles in 5.1. is that Balto-Finnic had a series of particles (perhaps adverbs) formed from pronominal stems (se- and $k u-$ at least, probably tä- and perhaps also jo- and $m i-)$ and adverbial derivational suffixes $-n n e-$ and $-(n) n i-$ (with or without lative ${ }^{*}-k$ or ${ }^{*}-s$ ). These terminative (and modal) endings became semi-productive in Finnish (witness (34) above) and fully productive in Estonian.

In the following I present several analyses of the history of the terminative. Although I eventually find fault with all of them, I should point out that these approaches assume at least some stage at which the terminative is to be analysed as an adverbial ending. My own viewpoint parallels more closely the analysis that I presented in section 4 for the abessive, i.e. morphosyntacticization and deaffixation.

\subsubsection{Collinder's coaffix theory}

Collinder (1960: 238) speculates that the terminative in Estonian (and the 
relics in the other Balto-Finnic languages?) goes back to Proto-Finno-Ugric. Nonetheless this hypothesis cannot be maintained even in light of Collinder's coaffix theory. Although he reconstructs *-ndik for the terminative in the parent language, neither this form nor the more generally accepted forms in $-n n e-$ and $-(n)$ ni- fit his theory without amendments. Collinder's coaffixes were $l, s, \xi$ and $k$, which combined with case endings (e.g. locative *-na and separative *-ta). The terminative does not have one of these coaffixes, nor is it identical to one of the primordial case endings (except perhaps the "terminative-dative" $-n$ ). Therefore I assume that the terminative is of more recent vintage.

5.2.2. Mägiste on case ending parallelism

Mägiste (1959) was of the opinion that the terminative ending *-nnik (< *-nnek via analogy to adverbs in *-lik) was originally a (pro)lative case ending in Proto-Balto-Finnic. Most Finno-Ugricists reconstruct case ending "triplets" for the parent language, especially for the inner and outer local cases (from Rätsep 1979: 27):

(36)

\begin{tabular}{|c|c|c|c|c|}
\hline ESSIVE & $*_{-n a}$ & PARTITIVE & $*$-ta & \\
\hline NESSIVE & ${ }^{*}$-sna & ELATIVE & *-sta & ILLATIVE \\
\hline DESSIVE & *-Ina & ABLATIVE & $*^{*}-$ ta & ALLATIVE \\
\hline
\end{tabular}

Mägiste, however, assumes a different triple for the essive row (p. 115):

ESSIVE *-na EXCESSIVE *-nta PROLATIVE *-nek

(Furthermore, Mägiste postulates *-lek for the allative instead of *-len.) Thus the essive triplet forms an almost perfect parallel to the outer local case triplet, especially -lta:-nta and -lek:-nek.

There are nevertheless problems in his reconstructions. First, one might expect *-nna instead of essive *-na, as a parallel to the other two in that column, *-sna and *-lna. Second, Mägiste's analysis does not account for the

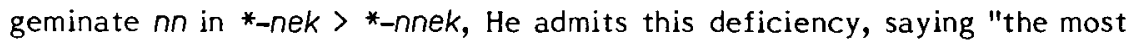
difficult question, which $I$ do not touch on here, is the origin of the the geminate $n$ in the Estonian case ending" (1956: 115 - 116). Third, this account fails to explain the relic forms in the other Baltic Finnic languages. It would indeed be peculiar that Estonian conservatively retains a case 
ending that is lost elsewhere in Balto-Finnic. Estonian is otherwise known to be an innovative daughter of Proto-Balto-Finnic.

\subsubsection{Kettunen and the postposition hypothesis}

Kettunen (1956: 11) sets up a straw man agglutination hypothesis whereby the modern terminative is the result of the cliticization of a former postposition (along the lines of the comitative in section 2). Although this hypothesis nicely explains the geminate $-n n-$, the first consonant of which can be seen as the $n$ of the genitive and the second as the first consonant in the postposition nek, Kettunen points out that no source word exists. In addition, this approach fails to account for the relic forms in the other BaltoFinnic languages.

\subsubsection{Alvre and Kettunen on sporadic agreement}

An alternative to the above two attempts can be found in Alvre (1971, 1972, 1974) and Kettunen (1956), who assume, as I do, that the terminative existed as an adverbial ending in Proto-Balto-Finnic. This approach accounts satisfactorily for the adverb relics in the Balto-Finnic languages, including Estonian (e.g. kuni and seni). In Estonian alone, then, the adverbial ending became productive and escaped into the nominal system as a clitic postposition.

According to Alvre's explanation, the terminative adverb was connected to the noun in much the same manner as a preposition (cf. modern Estonian kuni metsa-ni 'as far as the forest'), and then, striving for congruence, speakers inflected the terminative on the head substantive as well. After that, presumably $-n i$ spread as a case ending and the preposition kuni and any other terminative preposition was for the most part lost. Furthermore, under Alvre's analysis, in the original prepositional phrase the noun or noun phrase was in the illative case (thereby accounting for the lative meaning).

Thus from an original prepositional phrase with kuni and an illative noun (phrase):

(37) kuni metsa 'as far as the forest' (with illative of mets 'forest') congruence changed the illative into the terminative: 
(38) kuni metsa-ni

and later still the preposition was lost:

(39) metsa-ni

Rätsep (1979) criticizes this explanation on mostly phonological grounds. Synchronic Estonian should preserve the strong stem of the illative instead of the weak stem. That is, Alvre incorrectly predicts *jogeni in place of joieni 'up to the river'.

Kettunen (1956) sets up a similar hypothesis, only he uses the allative case in the original prepositional phrase, thus accounting for the weak stem (p. 11). Apparently he believed that the terminative preposition governed the allative case on the accompanying noun phrase. His version of the development procedes as follows:

(40) kuni jõe-le (government)

kuni jõe-ni (agreement)

$\emptyset$ jõe-ni (loss of preposition)

If kuni and the other terminative adverbs triggered agreement on a following noun, one has to wonder why they would not also have caused concord on each member of the noun phrase, i.e. each adjective. Thus how would Alvre and Kettunen explain the ungrammaticality of *kuni uueni jōeni from either *kuni uude jőkke (Alvre) or *kuni uuele jơele (Kettunen)?

\subsection{Morphosyntacticization and deaffixation}

I am in complete sympathy with Kettunen's and Alvre's ideas that the terminative ending was originally an adverbial formant, which in Estonian spread to the nominal case system. But the hypothesis that the adverbials developed into prepositions, triggered concord, and disappeared is simply wrong (or at best speculative).

Following Rätsep (1979), I assume that the once derivational suffix *-nni- (or -nne), an adverbial formant, became productive and spread from the lexicon into the syntax of Estonian. Morphosyntacticization as an innovation in Estonian satisfactorily accounts for the adverb relics in the other Balto-Finnic languages. The terminative had once been an affix, but is now a clitic postposition, so deaffixation has also taken place (though not necessarily at the same time as morphosyntacticization). 
Evidence for the derivational status of terminative ${ }^{*}-n n i-$ comes from two sources. First, it fails to occur morphotactically where case affixes always occur in Balto-Finnic languages. And second, it lies inside derivational suffixes.

Case affixes are morphosyntactically outermost of the inflectional affixes:

STEM-DER.SUFFIXES-COMPAR/SUPERL-PL-CASE-(POSS.SUFFIXES) INFLECTIONAL SUFFIXES

But in words like Finnish tuo-nne-mma-s 'farther toward that direction', tuo-nne-mpa-na 'farther that way', tuo-nne-mpa-a 'from farther that way', tä-nne-mmä-s 'more over here' etc., si-nne-mmä-s 'more over there' etc., terminative -nne- lies inside the comparative -mma-/-mpa-. Although here it might be the first of the inflectional affixes, it could easily be described as the last of the derivational affixes.

That $-n n i-$ is indeed derivational is shown by its appearance in Finnish inside the derivational affix - kka in the postposition saannikka 'as far as, up to' (Hakulinen 1979: 233) and inside derivational suffixes in tuo-nn-oin, tuo-nn-oinen, and tuo-nn-oittain 'a while ago, some time ago' and tä-nn-immä-inen 'nearest this way' (all with loss of the vowel). Since inflections universally fail to lie on the base side of derivational affixes, we count this example as evidence that the terminative -nni- was itself derivational.

Similarly, Kettunen (1956: 22) mentions archaic Estonian terveniste [pro tervenisti] 'ganz', koguniste [pro kogunisti] 'vollkommen', and pooleniste [pro poolenisti] 'zur Hälfte, teilweise', in which the terminative -ni lies inside the adverb suffix -sti. Furthermore, Estonian has forms like tänine and senine, both adjectives meaning roughly 'still in use, continuing to exist, so $f^{\prime}$ ', in which $-n i$ lies inside the derivational suffix -ne.

Positing *-n n)nik as an adverb formant now allows us to observe some parallelism in a larger set of adverbial suffixes (each formerly ending in lative $*-k)$ :

$$
\begin{aligned}
\text { (41) }- \text { sti } & <* \text {-stik (e.g. kenasti 'nicely') } \\
-t i & <*-t t i k \quad \text { (e.g. pikuti 'lengthwise') } \\
-1 d i & <*-l t i k \quad \text { (e.g. pooleldi 'half, partly, halfway') } \\
-1 i & <*-l i k \quad(\text { see (27) above) } \\
-n i & <*-n n i k \quad \text { (e.g. pärani 'wide (open)') }
\end{aligned}
$$


Each adverb derivational suffix has the vowel $i$; each ended formerly in lative *-k; and each (to a certain extent, idiosyncratically) attaches to a stem in the weak grade. This last fact helps explain how easily NOUN + *-nnik slipped into the clitic postposition category established by the comitative. The host for *-nnik was already the weak grade, so that the weak grade-qua-genitive stem found in the modern terminative still reflects the older adverbial stem. The discrete morph $-n$ of the genitive was lost (becoming isomorphous with the bare stem) by the time the bound postpositions emerged to form a clear category in the language.

\section{On the development of agreement}

From Late Balto-Finnic we expect Estonian to have inherited an inflectional suffix abessive and a derivational suffix terminative. Clearly the syntacticization of terminative $-n i$ took place in early Estonian. The deaffixation of the terminative and the abessive was an innovation in (late) Old Estonian, apparently concurrent with the agglutination of comitative $-g$ a. The facts are not transparent, but the development of adjective-noun concord in the language allows us to narrow down the timing of deaffixation and the emergence of the clitic postposition category in Estonian.

Tauli (1966: 260 - 269) and Collinder (1965: 63) relate that adjectivenoun agreement developed fairly recently - starting in the pre-Balto-Finnic period, continuing through the break up of the Balto-Finnic languages. In the Permic branch of Finno-Ugric, only the Balto-Finnic languages have full agreement systems for both case and number. Sámi has what is called "partial" agreement, namely case agreement (not number) between a small class of adjectives their head nouns. Most adjectives in the Sámic languages remain in the attributive form.

Old Estonian supports the idea of agreement as a recent phenomenon in Balto-Finnic. Nurkse (1937) shows that the old literary language had another kind of partial agreement. This agreement system was, according to Nurkse, based on the syllabic length of the case ending. Short, non-syllabic cases had agreement; long syllabic cases lacked it.

(42) NON-SYLLABIC, CONGRUING CASES:

nominative (stem change) 


$\begin{array}{ll}\text { genitive } & \text { (stem change) } \\ \text { partitive } & -\mathrm{t},-\mathrm{d}, \text { (stem change) } \\ \text { illative } & \text { (stem change) } \\ \text { inessive } & -\mathrm{s} \\ \text { elative } & -\mathrm{st} \\ \text { adessive } & -\mathrm{l} \\ \text { ablative } & -\mathrm{lt} \\ \text { translative } & -\mathrm{ks} \\ \text { (43) SYLLABIC, NON-CONGRUING CASES: } \\ \text { allative } & -\mathrm{le} \\ \text { illative } & -\mathrm{sse} \\ \text { comitative } & -\mathrm{ga} \\ \text { abessive } & -\mathrm{ta} \\ \text { terminative } & -\mathrm{ni} \\ \text { essive } & -\mathrm{na}\end{array}$

The comitative and the essive are temporarily left aside, since we know that they have a more recent origin in Estonian than Nurkse admits. The illative allomorphs are split into two groups - the non-syllabic, congruing stem change allomorphs and the syllabic, non-congruing -sse allomorph. The modern language, in comparison, has both allomorph classes patterning alike. They are both congruing morphs. I assume here that allomorphic pressure caused -sse to accept concord. Likewise, one could easily make the case that paradigmatic pressure from the two outer local cases (i.e. the adessive and the ablative) forced the third outer local case (namely the allative) into the congruing pattern.

Some of the modern dialectal systems retain the Old Estonian split agreement system (see Nurkse 1937).

The abessive and terminative case endings, however, had no such pressure to switch categories, so that when the agglutination of comitative -ga took place, they were reassigned to the new clitic postposition category established by the comitative. The last to (re)enter the system is the turnof-the-century borrowing, the essive -na.

Thus development within Estonian is complex. The embryonic agreement system inherited from Late Balto-Finnic develops in early Old Estonian according to the syllabic or non-syllabic nature of the case ending. In late 
Old Estonian there is realignment and reanalysis: most cases wind up as suffixes, but some are wooed into the clitic postposition category. The category emerges only upon the cliticization of postposition kaas.

(44)

Pre-Old Estonian

Early Old Estonian

Late Old Estonian

Modern Estonian

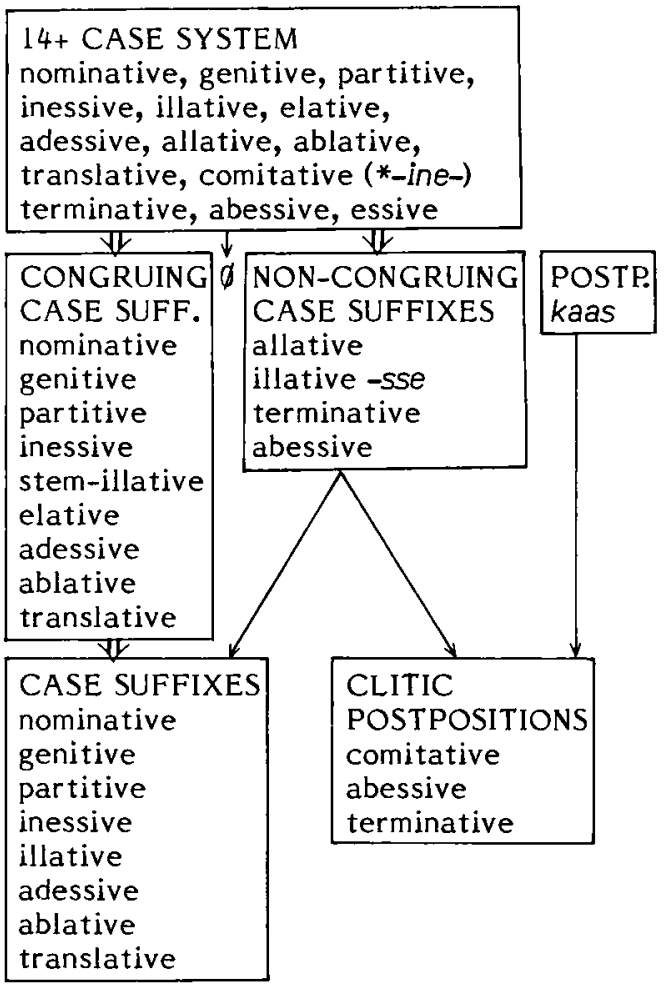

essive bor rowed as a CLITIC POSTPOSITION

\section{Conclusion}

The clitic postposition category has a shallow history as a unit in Estonian. Its members, though, are ancient semantic and form categories in the language, with at least the essive and abessive dating back to Proto-FinnoUgric.

The means by which the clitic postpositions arrived at their present state are diverse. The comitative is a straightforward cliticization from a 
former postposition. The essive was lost and then borrowed back into the language as the turn of the century. The abessive and terminative were affixes that shifted into the clitic postposition category due to their lack of adjective-noun agreement. Reinterpretation of the phrasal affixes -ta and $-n i$ as bound words (i.e. deaffixation) was brought about by the agglutination of the comitative -ga. Deaffixation here is a direct consequence of cliticization of the comitative postposition kaas.

The only postposition to cliticize in Old Estonian is comitative kaas. In other Balto-Finnic languages one finds similar former postpositions among the comitative *kerta-, prolative *moo-, peripheral *loo-, and terminative *saa- stems (Oinas 1961, Stoebke 1968). And in most of the relevant dialects these former full postpositions are now clitic postpositions, as in Estonian. But in some dialects one finds further downgrading into affixes, as witnessed by adjective-noun concord in Vepsian ( 45 - 47), adapted from Oinas (1966):

(45) verihiž-ide-(n)ke kündI'-id'e-(n)ke

bloody -PL -COM tear -PL -COM

'with bloody tears'

(Šimjärv dialect)

(46) kuivad-mö kujoštt-mö, vašššst-mö vagoštt-mö

dry-PROL lane-PROL copper-PROL furrow-PROL

'along the dry lane, along the copper furrow'

(Noidal-Rebag dialect)

(47) habāže-rost pehko-rost

hollow-PERIPH aspen-PERIPH

'to the hollow aspen tree'

(Arskaht dialect)

Similar affixes are cited by Palmeos (1973), Comrie (1980), and others.

Oinas discusses the chronology of the cliticization of the different postpositions in the various Balto-Finnic languages. For the most part the phonological reductions begin in the southern branch in the 15th - 17th centuries (earlier for Votian and S. Estonian, later for N. Estonian). Although the NE languages show more extensive downgrading of postpositions than do the southern languages, Oinas argues that cliticization took place later in the NE group of languages. Thus the clitic postposition category in 
N. Estonian has proved to be somewhat more stable than have cognates in other Balto-Finnic languages.

JOEL ASHMORE NEVIS

\section{REFERENCES}

Ahrens, E. 1843 [1853]. Grammatik der Ehstnischen Sprache I.

Alvre, Paul. 1971. Terminatiivseist konstruktsioonidest terminatiivini. Keel ja kirjandus 6: 345 - 351, 9: 535 - 541 .

- 1972. Terminatiivseist konstruktsioonidest terminatiivini. Keel ja kirjandus 8: $467-473$.

- 1974. Terminatiivseist konstruktsioonidest terminatiivini. Keel ja kirjandus $1: 7-14,4: 219-225,6: 347-355$.

Callaghan, Catherine. 1972. Increase in Morphological Complexity. Proceedings of the Eleventh International Congress of Linguists, ed. by Luigi Heilman.

Collinder, Björn. 1960. Comparative Grammar of the Uralic Languages. Almqvist \& Wiksell, Stockholm.

- 1965. An Introduction to the Uralic Languages. University of California Press, Berkeley and Los Angeles.

Comrie, Bernard. 1980. Morphology and Word Order Reconstruction: Problems and Prospects. Historical Morphology, pp. 83 - 96. Edited by Jacek Fisiak. Mouton.

Décsy, Gyula. 1965. Einführung in die finnisch-ugrische Sprachwissenschaft. Otto Harrassowitz, Wiesbaden.

Gutsleff [Gutslaff], J. 1648. Observationes grammaticae circa linguam esthonicam. Dorpat.

Hakulinen, Lauri 1979. Suomen kielen rakenne ja kehitys.

Helle, Thor 1732. Kurzgefässte Anweisung zur Ehnstnischen Sprache. Reval.

Heller, Fr. 1822. Versuch über das Wesen und den Gebrauch der ehstnischen Casen. Beiträge zur genauern Kenntnis der ehstnischen Sprache 15.2, 16.19.

Hornung, J. 1893. Grammatica Esthonica. Riga. 
Hupel, A. W. 1780. Ehstnische Sprachlehre für beide Hauptdialekte. Riga.

Janda, Richard. 1981. A Case of Liberation from Morphology to Syntax: The Fate of the English Genitive-Marker fels. Syntactic Change. Natural Language Studies 25: $59-114$.

Jakobson, Roman 1971. [1938]. Sur la theorie des affinités phonologiques entre les langues. - Roman Jakobson: Selected Writings I: Phonological Studies. Mouton, the Hague. Originally presented at the (1936) Eighth International Congress of Linguists, Copenhagen, and reprinted from the Acts of that congress (1938).

Jeffers, Robert and Zwicky, Arnold M. 1980. The Evolution of Clitics. Papers from the Fourth International Conference on Historical Linguistics. Also in OSU WPL 24: $55-64$.

Kask, Arnold 1972. Eesti keele ajalooline grammatika. Häälikulugu. Tartu Riiklik Ủlikool.

Kettunen, Lauri 1956. Die Herkunft der Terminativs, Genitivs, Instruktivs, und Komitativs. Suomalaisen tiedeakatemian julkaisuja (B) 98.2: 1 - 49.

Korhonen, Mikko 1974. Die Konjugation im Lappischen. Morphologischhistorische Untersuchung. II. Die nominal Formkategorien. SUST 155.

- 1979. Entwicklungstendenzen des finnisch-ugrischen Kasussystems. FUF 43: $1-21$.

Lehiste, Ilse 1969. 'Being' and 'Having' in Estonian. Foundations of Language. 5.3: $324-341$.

Mägiste, Julius 1959. Terminatiivipäätteiden ja -rakenteiden alalta. Verba Docent, pp. $114-134$.

Nevis, Joel A. 1982. Suffix Versus Clitic: Four Estonian Case Endings. CLS 18: $400-406$.

- 1985. Finnish Particle Clitics and General Clitic Theory. PhD Dissertation, the Ohio State University. OSU WPL 33.

- 1986a. Deaffixation and Decliticization in Northern Saame: Abessive taga. To appear in OSU WPL 34.

- 1986b. The Comitative, Terminative, Abessive, and Essive as Clitic Postpositions in Estonian. To appear in UAJb 7.

- 1986c. Decliticization in Old Estonian. To appear in OSU WPL 34.

- 1986d. On the Origin of Abessive -ta in Estonian. Paper read at the Fourth Annual Meeting of the Finno-Ugric Studies Association of Canada, Winnipeg. 
Nurkse, Rein. 1937. Adjektiiv-atribuudi kongruentsist eesti keeles. Akadeemilise Emakeele Seltsi Kirjastus, Tartu.

Oinas, Felix. 1961. The Development of some postpositional Cases in BaltoFinnic Languages. SUST 123.

Palmeos, Paula. 1973. Hilistekkinud käänded karjala Djorža murrakus. SUSA 72.

Penttilä, A. 1957. Suomen kielioppia. WSOY, Porvoo.

Rätsep, Huno. 1979. Eesti keele ajalooline morfoloogia II. Tartu Riiklik Ulikool.

Raun, Alo and Saareste, Andrus. 1965. Introduction to Estonian Linguistics. Ural-Altäische Bibliothek, Wiesbaden.

Saareste, Andrus. 1938. Agenda Parva (1622) keelest. Eesti Keel, p. 73 - 96.

Setälä, E. N. 1890 - 1891. Yhteissuomalainen äännehistoria 1 - 2. Helsinki.

Stoebke, Renate. 1968. Die Verhältniswörter in den ostseefinnischen Sprachen. Indiana University Publications, Uralic and Altaic Series 93. Bloomington Indiana.

Tauli, Valter. 1966. Structural Tendencies in Uralic Languages. Indiana University Publications, Uralic and Altaic Series 17. Bloomington Indiana.

Thomason, Sarah Grey. 1981. Are there linguistic prerequisities for contactinduced change? Paper read at the University of Milwaukee Symposium on Language Contact. 